\title{
Science and technology parks: measuring their contribution to society through social accounting
}

\section{Víctor Blázquez Ricardo Aguado José Luis Retolaza}

ABSTRACT: Science and Technology Parks (STPs) have made a positive contribution to regional development in the last decades. In general, the assessment of their level of performance has been based on two major variables: number of new companies and number of new jobs created. In this paper we propose the use of social accounting to measure the social value (SV) generated by STPs as an additional tool to assess the level of contribution of STPs to social development. Social accounting could be of interest for policy makers and regional governments in order to evaluate regional STPs and their social performance. In addition, in this paper we present an innovative methodology for calculating SV. Instead of using primary data to calculate SV (through interviews or consultations with individual stakeholders), we propose the use of secondary data available in open databases to measure SV. In this way, the measurement of SV for a large number of individual organizations can be achieved using a limited amount of resources. In this line, and as a seminal implementation of this methodology, we calculate the SV generated by four STPs in two different regions and countries belonging to the European Union using secondary data. Thus, the main contribution of the paper is twofold: on one hand it proposes social accounting to assess the performance of STPs through the calculation of SV, and on the other hand it implements a new methodology to calculate $\mathrm{SV}$ which requires the use of a lesser number of resources.

KEYWORDS: Social Value, Stakeholder Theory, Science and Technology Parks, Regional Development; Social Accounting.

ECONLIT CODES: M41, 038, R11.

How to cite this article/Cómo citar este artículo: BLÁZQUEZ, V., AGUADO, R. \& RETOLAZA, J.L. (2020): "Science and technology parks: measuring their contribution to society through social accounting", CIRIEC-España, Revista de Economía Pública, Social y Cooperativa, 100, 277-306. DOI: 10.7203/CIRIEC-E.100.18169.

Correspondence: Víctor Blázquez, victor.blazquez@supsi.ch, University of Applied Sciences and Arts of Southern Switzerland, ORCID ID: 0000-0002-0952-9993; Ricardo Aguado, ricardo.aguado@deusto.es, University of Deusto, ORCID ID: 0000-0002-2671-5691; José Luis Retolaza, joseluis.retolaza@deusto.es, University of Deusto, ORCID ID: 0000-0001-7089-4861. 


\section{Resumen extendido}

\section{Parques científicos y tecnológicos: una medición de su contribución a la sociedad a través de la contabilidad social}

Los Parques Científicos y Tecnológicos (PCyT) han venido realizando una contribución positiva al desarrollo regional en las últimas décadas (Poonjan \& Tanner, 2020). Estos PCyT, al menos en el contexto europeo, tienen como misión principal el estímulo del desarrollo social en sus territorios (Guadix et al., 2016). En general, la medición de su nivel de éxito en esta labor se ha basado en la evolución de dos variables: número de nuevas empresas y número de nuevos puestos de trabajo creados. Sin embargo, diferentes autores (Lecluyse et al., 2019; Fulgencio, 2017) han puesto de manifiesto la conveniencia de desarrollar nuevas mediciones que recojan de una manera más completa el valor generado en los PCyT para el conjunto de la sociedad. En este artículo proponemos el uso de la contabilidad social para medir el valor social (VS) generado por los PCyT como una herramienta adicional para calcular el nivel de contribución (éxito) de los PCyT al desarrollo regional. Esta nueva herramienta podría ser del interés de los decisores políticos y de los gobiernos regionales para evaluar los PCyT regionales y su impacto en el desarrollo regional. Adicionalmente, en este artículo presentamos una manera innovadora de calcular el VS que permite su aplicación simultánea a un número elevado de empresas utilizando una cantidad limitada de recursos. En lugar de utilizar datos primarios para calcular el VS (a través de entrevistas o consultas con stakeholders individuales), proponemos el uso de datos secundarios accesibles en bases de datos abiertas. De este modo, la medición del VS generado por un elevado número de organizaciones individuales puede ser llevada a cabo utilizando un número limitado de recursos. Siguiendo este razonamiento, y como una aplicación de esta metodología, en el artículo hemos realizado la medición del VS generado por cuatro PCyT ubicados en dos regiones pertenecientes a diferentes países de la Unión Europea a través de datos secundarios. En unión con este análisis planteamos la hipótesis a contrastar a lo largo del artículo: la generación de valor social por social por parte de las empresas ubicadas en los PCyT es superior a la generación de valor social por parte de las empresas ubicadas en su región o territorio. Las contribuciones de este trabajo pueden resumirse en tres. Por un lado, se plantea una innovación metodológica al sustituir la utilización de datos primarios por datos secundarios a la hora de calcular el valor social. Este cambio posibilita el cálculo del valor social para un número elevado de organizaciones sin la necesidad de incurrir en la utilización de un número elevado de recursos. En segundo lugar, se aplica esta nueva metodología al cálculo del valor social generado por las empresas ubicadas en PCyT, respondiendo a las cuestiones planteadas por Fulgencio (2017) y Lecluyse et al. (2019). Por último, proponemos a los equi- 
pos gestores de PCyT y a los responsables políticos el cálculo del valor social para gestionar las relaciones de los PCyT con sus stakeholders.

A la hora de realizar el cálculo del valor social, en el presente trabajo vamos a utilizar como base el modelo SPOLY, que recoge el valor generado por la empresa desde el punto de vista de los partícipes sociales (stakeholders) con los que la empresa se relaciona (Retolaza et al., 2016a). En este modelo, el valor social sería la suma del valor social de mercado (VS-SIEA), el valor de no mercado y el valor emocional. Sin embargo, la utilización de datos secundarios limita el alcance de la medición del valor social, que queda reducida únicamente al valor social de mercado (VS-SIEA). Para completar este valor, habría que recurrir a la utilización de datos primarios.

A la hora de proceder con la implementación de la nueva metodología basada en datos secundarios se ha elegido un primer grupo de cuatro PCyT ubicados en dos regiones de dos países distintos pertenecientes a la Unión Europea. Tras la realización de esta primera implementación de la metodología, los autores plantean su traslación al conjunto de los PCyT en Europa en un futuro trabajo.

El procedimiento seguido en este trabajo para el cálculo del valor social (VS-SIEA) en los PCyT se desarrolla a lo largo de cuatro fases: 1) recolección de datos primarios, 2) extracción de datos secundarios de la plataforma ORBIS, 3) filtrado de las empresas de las que se cuenta con suficiente información como para seguir con el proceso y 4) cálculo del VS-SIEA de las empresas ubicadas en cada PCyT. En la fase 1 es necesario solicitar a las sociedades gestoras de los PCyT el nombre de las empresas ubicadas en el parque, su número VAT y el número de empleados de cada empresa en el PCyT. A partir de estos tres únicos datos primarios (que se pueden obtener mediante un trámite único con la sociedad gestora del PCyT) se pueden conseguir todos los datos necesarios para el cálculo del VS-SIEA de cada empresa a través de la plataforma ORBIS (fase 2). En la fase 3 se realiza una comprobación sobre la calidad de los datos descargados de la plataforma ORBIS (datos obsoletos o falta de datos para los años recientes 0 datos incompletos). En esta fase se seleccionan aquellas empresas de las que existe información suficiente para continuar con el procedimiento. En la fase 4 se realiza el cálculo del valor social (VS-SIEA) para las empresas ubicadas en los PCyT, sobre la base del modelo SPOLY.

En este trabajo se ha realizado una segunda medición utilizando la misma metodología para poder responder a la hipótesis planteada al comienzo del mismo: la generación de valor social por parte de las empresas ubicadas en los PCyT es superior a la generación de valor social por parte de las empresas ubicadas en la región o territorio. Para ello, se ha procedido a medir el valor social (VS-SIEA) generado por el conjunto de empresas de cada territorio administrativo en los que operan los cuatro PCyT de referencia. Tras esta medición se ha procedido a comparar el valor social (VS-SIEA) por empleado y por empresa en cada uno de los 4 casos por partida doble: en cada PCyT y en cada uno de los 4 territorios de referencia. Los resultados señalan que el valor por empresa es claramente superior en los PCyT en comparación con sus respectivos territorios. Sin embargo, los resultados son mixtos a la hora de comparar el valor por empleado. En este caso, solamente en uno de los cuatro PCyT este valor supera al valor de 
referencia del territorio. Por tanto, la hipótesis inicial de este trabajo se cumple solamente de manera parcial.

Los hallazgos de este trabajo responden a las contribuciones planteadas en su inicio, y al estudio de la hipótesis de partida. Por un lado, el trabajo demuestra que es factible la utilización de datos secundarios para el cálculo del valor social (VS-SIEA) en PCyT y a nivel regional. Esto ha supuesto el análisis de miles de organizaciones, utilizando un número de recursos (incluyendo el tiempo) limitado. En segundo lugar, se proporciona una respuesta a las preguntas planteadas por Fulgencio (2017) y Lecluyse et al. (2019), presentando una manera posible de calcular el valor social (VS-SIEA) generado en los PCyT. Adicionalmente, se contrasta la hipótesis inicial presentada en el trabajo, validándose parcialmente. Toda esta información podrá ser utilizada por las sociedades gestoras de los PCyT y por los decisores políticos para una gestión de los PCyT que considere la generación de valor en sus partícipes sociales.

Por otro lado, la metodología desarrollada en este trabajo presenta una serie de limitaciones. En primer lugar, si la calidad de los datos secundarios es baja, se resentirá también la calidad del valor social calculado a partir de ellos. En segundo lugar, sería de interés la realización de una medición completa del valor social generado en al menos un PCyT por medio únicamente de datos primarios para luego poderla comparar con la medición realizada con datos secundarios. En tercer lugar, el trabajo se ha realizado para un número limitado de PCyT, y tendría interés su extensión al conjunto de los PCyT en la Unión Europea y Reino Unido en un siguiente paso.

Palabras clave: Valor Social, Teoría Stakeholder, Parques Científicos y Tecnológicos, Desarrollo Regional, Contabilidad Social 


\section{Introduction}

Science and Technology Parks (STPs) are well established and globally spread. In Europe, in particular, STPs tend to be used as potential drivers for territorial development and are, therefore, considered and promoted in innovation and regional development policies (Poonjan \& Tanner, 2020; Martínez-Cañas \& Ruíz-Palomino, 2011). In fact, many STPs in Europe arise from public or public-private partnership initiatives, in the context of territorial development and economic promotion policies (Guadix et al., 2016). Those STP initiatives usually do not seek profit, and in some cases are stablished under the form of a foundation. These characteristics places them into the wide movement of the social economy (Alcaniz, Aguado \& Retolaza, 2020). Coherently, the concept or model of STPs is combined with Etzkowitz's notion of the triple helix (Etzkowitz \& Zhou, 2018). It is a model in which the government-industry-university trio must coexist and benefit from one another in order to promote business innovation (e.g. new entrepreneurial activities and new jobs) and at the same time generate positive effects on the community, all in a sustainable way (Lecluyse et al., 2019). In this perspective, we refer to the definition of STP developed by the International Association of Science Parks and Areas of Innovation (IASP), that states: "a science park is an organisation managed by specialized professionals, whose main aim is to increase the wealth of its community by promoting the culture of innovation and the competitiveness of its associated businesses and knowledge-based institutions" (Hobbs et al., 2017, p. 958).

In relation to the concept of STP, the measurement of performance and impact on society and territory are still a theme of discussion, but also of particular interest, both in the scientific community and among practitioners, as well as for policy makers (see for example (Yan et al., 2018) and (Meseguer-Martinez, Popa, \& Soto-Acosta, 2020)). STPs are very complex ecosystems with very delicate equilibriums, as they have to balance the interests between public and private initiative and are responsible to multiple stakeholders. If also this aspect is considered, the measurement of a park's performance can be observed, read and interpreted from different perspectives; thus bringing a higher degree of complexity to the analysis (Lyra \& Almeida, 2018; Ng et al., 2019; Ribeiro et al., 2016). In fact, the same performance observed by different stakeholders can take on very different connotations, being for some very positive and, at the same time, very negative for others. There is also an intense discussion and discordance between scholars about the positive contribution of STPs to their respective territory of reference. Equally, there are still open questions about how much the territorial context influences the STPs performance, and how much the opposite effect occurs, i.e. the STP boosting the territory's performance (Poonjan \& Tanner, 2020; Vásquez-Urriago et al., 2014). The issues revolve around matters related to stakeholders, territory and performance. The concern related to the STP's governance and management is certainly another issue of interest closely related to these three factors, so it is not possible to make thoughts without considering this aspect (Lyra \& Almeida, 2018).

Regarding the STP performance, it is noted that it is generally measured, for example, in terms of jobs created, number of companies established/created and turnover generated by 
the park community of companies (Lecluyse et al., 2019). However, it has been noted that these do not measure the impact in terms of value creation for society, understood not only as the company's community that constitute the STP but also in its broader meaning (Albahari et al., 2019; Albahari et al., 2017). In this sense, there is a growing interest, and related debate, in the development of techniques, approaches and methodologies which can allow the measurement of the social value generated by a given STP, and, in particular, also the value for all the related stakeholders.

Accordingly, the review made by Lecluyse et al. (2019) shows that this aspect needs further development. Also in this direction, we make reference to the study conducted by (Fulgencio, 2017) which aimed at the construction and identification of a framework that allows to categorize the social value according to the specific stakeholders of the innovative ecosystem in which the STP is inserted. What follows, however, is that up to that moment there were no clear models or methodologies to measure and quantify this social value (Fulgencio, 2017).

In this regard, social accounting can be considered a valuable tool for the measurement and quantification (monetization) of this social value, and it is well suited for the reconstruction of the value distribution among stakeholders (Gray, 1994; Retolaza et al., 2015; Aguado \& Eizaguirre, 2020). In particular, reference is made to the polyhedral model of social value analysis (SPOLY - Social Polyhedral Model) (Retolaza et al., 2016a) based on Freeman's stakeholder theory (1984). In this sense, there are already studies that demonstrate its application to specific corporate and institutional contexts (Retolaza \& San-Jose, 2018; Aguado \& Retolaza, 2020), such as the tertiary sector in general, universities (Ayuso et al., 2020), religious educative organizations (Retolaza et al., 2020), cooperatives and non-profit organisations, as well as to specific companies (San-Jose et al., 2017), and other institutions (Lazcano et. al, 2019; Retolaza et al., 2015; Retolaza et al., 2016a). The applications conducted so far put at the centre of the analysis a single entity around which they reconstruct and calculate the social value generated and distributed to the main stakeholders. It should be noted that these processes of reconstructing social value are generally carried out in cooperation with the organisation under study and require access to primary accounting data. This very accurate way of working requires a considerable investment of time but allows a complete analysis considering the three areas of blended social value analysis, i.e. monetizing for each group of stakeholders the social impact of economic activity (SIEA), the socio-economic return (S-ER), the specific social value (SSV), and the emotional value (Retolaza et al., 2016a; Retolaza et al., 2015).

As it can be guessed, this methodology is well suited to be adapted and made functional for the measurement (monetization) of the social value that is generated and distributed to different stakeholders by the companies in the STPs. Given the atypical context (STPs), which passes from the analysis of a single organisation to the analysis of a community of corporations, the focus is on the area of social impact of economic activity (SIEA). This part of the social value analysis is considered because it is more suitable to be carried out with secondary accounting data and applicable to a large scale (simultaneous analysis of several companies). For this study, the decision was to focus mainly on the following stakeholders: employees, suppliers, customers, shareholders, financial entities and public administration (Freeman et al., 2010). 
In this context, the adopted definition of social value is "the utility provided by the set of social assets generated by an organisation for the stakeholders or interest groups related to the organisation" (Lazcano et al., 2019, p. 149). More precisely, the added value generated by organisations inside STPs will be considered for the monetization of social value. The methodological support for the value-added analysis is the one established by the AECA (Association of Accounting and Management in Spain) (Gonzalo \& Perez, 2017). At the same time, the analysis of the value induced by suppliers will follow the general guidelines proposed by the not-forprofit accounting organisation GEAccounting (Retolaza \& San-Jose, 2018). In practical terms, the financial data of the enterprises located in STPs, and in the region as well, are used to calculate the value generated by the corporations of each STP and by the ones placed in a given region. To implement this analysis, we use data about individual companies available on the ORBIS Platform (Companies Financial Database -Bureu Van Dijk- A Moody's Analytics Company).

Consistently, this paper aims to present a methodology based on social accounting principles that allows measuring and monetizing the social value generated and distributed by STPs. At the same time, in order to demonstrate its applicability, an analysis will be explained involving four European STPs: the three STP belonging to the Basque Network of STPs (Basque Country, Spain) and the Linköping Science Park (Östergötland, Sweden), which are all IASP members.

Moreover, it is important to state that there is a key hypothesis underlying this research work. It is hypothesised that the social value created by corporations inside STPs for their stakeholders is higher than the social value generated by corporations in the region.

As discussed above the originality of this study is twofold. On one hand, it is based on the social accounting principles used to quantify and monetize the social value created by corporations, applied to STPs in this case. On the other hand, it considers the principles of stakeholder theory and social development as part of the final objectives of economic activity. The contributions of this study can be summarized in three main areas. In the first place, this work will introduce an innovation in the methodology currently used to calculate the social value generated by corporations. Instead of using primary data, we will propose the use of secondary data to calculate social value (SV). Specifically, we will calculate the SIEA part of social value, due to the specific methodology implanted in this case. This innovation makes possible the calculation of social value for a larger number of economic entities without devoting a great number of resources. Secondly, we will apply this methodology to the measurement of SV-SIEA in STPs, filling the literature gap detected by Fulgencio (2017) and Lecluyse et al. (2019), around the need to develop methodologies to measure the SV-SIEA generated by STPs. In the third place, we propose the use of this tool to policy makers, regional governments and STP managers, so that they can take decisions about STPs based on accurate information about their contribution to social development.

The paper is structured as follows. In Sect. 2 we will present the methodology adopted and its adaptation to the STP contexts as well as to the territorial analysis of social value. In Sect. 3 we will present and discuss a first implementation to the Basque Network of STPs and the 
Linköping Science Park. Finally, we will highlight the main conclusions, recognize limitations, and propose new paths of inquiry in this line of research.

\section{Methodology}

The development of this methodology demonstrates that it is feasible to calculate and monetize the social value generated and distributed by a given STP's community of companies. In particular, this section will prove that it is possible to obtain an accurate estimate of the social impact of economic activity (SIEA) according to the principle of the SPOLY model using secondary data. Other authors have used different approaches. For instance, Gray (1994) and Mook (2007) have proposed the use of the Value Added Statement (VAS) for similar purposes. However, there are some differences between VAS and SPOLY. On one hand, VAS is focused on the measurement of added value, while SPOLY considers a broader number of sources of value. In addition, SPOLY has a phenomenological base which introduces the interests of stakeholders from their own point of view directly into the analysis (San-Jose, Retolaza and Freeman, 2017).

The whole research was designed to minimize the invasiveness of the collection of primary data from individual organisations and at the same time to develop analytical criteria that can be standardized, generalized and adapted to specific national and regional contexts, in order to allow an extension of the study presented in section three at the European level. In fact, for the application of this methodology to STPs, only three key pieces of information are needed as primary data: company name, company VAT number and number of employees at the workplace located in the STP. Thanks to these three primary data, provided by the entity that manages each STP, it is possible to reconstruct the community of companies established in the STP and, thanks to the identification of the individual companies that are part of it, it is possible to proceed with the collection of secondary data to apply the methodology of social value (SV-SIEA) calculation. All this secondary data, in the case of this paper, has been collected from the ORBIS database. In addition, specific national data about taxation has been contrasted with the database DOING BUSINESS - Measuring Business Regulations (World Bank Group).

These methodological choices derive fundamentally from the particular needs of the application context, i.e. the field of STPs, each of which requires the analysis of all the companies in the community of the given STP in order to calculate the generated and distributed social value. A direct application, in a cooperative form, of the SPOLY model would need an active involvement both of the entity that manages the park and of all the companies that are located in the park. This procedure could certainly provide a more precise result, but it requires the full commitment of all the actors involved in the analytical process. Working together with many interlocutors (e.g. 100 organisations, as per average in an STP, according to Aguado (2007)), and depending on their active contribution (e.g. providing primary data), leads to an excessive organisational complexity in the application of the methodology and, consequently, very long execution times and often unattainably large budgets. In general terms, the application of the 
methodology in its entirety to a single organisation can require from six months to a year and a half of work, all this assuming a situation of full commitment and active participation by all involved actors (Aguado, Retolaza, \& Alcañiz, 2019).

In order to reduce the complexity and the time of analysis, the decision was to adapt the methodology to operate with a single interlocutor, the park management entity, and replace the primary accounting data with secondary data obtainable from the ORBIS Platform. As previously shown, the management entity has the information relating to the companies' VAT numbers, which allows us to trace the company accounting data published on the platform. In this way, the procedure is more streamlined and controllable and potentially applicable to several STPs at the same time. Using company accounting data, as discussed above, we can calculate the social impact of economic activity (SIEA) as indicated in the in the social accounting model which we will follow.

Adapting the methodology in such a way still allows a very good estimate of the social value (although we will focus only in the SIEA part of it), while maintaining a non-invasive approach and working purely with secondary data. In general, the purpose of this adapted methodology is to provide values that allow a first measurement of the value generated by the companies of the STP community for the whole society, attending to each of the stakeholders and regional agents that are part of that society.

For the development of this methodology adapted to the context of the STPs, the decision was to collaborate with the Basque Network of STPs (Basque Country, Spain), which showed a keen interest in the topic. The work done with this organisation has allowed a better understanding of the world of STPs and a first contact with one of these realities. The methodology has also been optimized for the calculation of the social value generated and distributed by companies located in a given territory, again in terms of social impact of economic activity (SIEA). This will allow the comparison with the SIEA generated inside STPs. To conclude the research, once the methodology was completed and refined, the Basque Network of STPs made it possible to involve the Linköping Science Park (Östergötland, Sweden) for a first application of this methodology.

The next subsections will present both the adaptation of the methodology to the context of STPs, the proxies used for estimating social impact of economic activity (SIEA) and the adaptation of the methodology to the territorial context.

\subsection{Adapting of the SPOLY model procedure to the STP context}

As explained above, to analyse the social value generated and distributed by STPs we focus on the area of analysis related to the social impact of economic activity (SIEA) and consider the following stakeholders: workers, suppliers, customers, shareholders, financial entities and public administration. 
Basically, the procedure consists of four main steps as follows: 1) Primary data collection, 2) Data extraction from the ORBIS Platform, 3) Filtering of the company population data and 4) Calculation of social impact of economic activity (SIEA).

\section{Step 1: Primary data collection}

The primary data to proceed with the application of the methodology are three, namely: the name of each company at the STP, the related European VAT identification number and the number of employees in the company's workplace at the STP. Name and VAT number are used to identify the companies within the ORBIS platform, from which all the information and data necessary to carry out the analysis are extracted. In this way, it is possible to switch to the use of secondary data to implement the social value calculation. The information related to the number of employees serves to weigh the value generated by the company in that specific STP. It must be considered that in STPs there are also multinationals or multi-site companies, which do not have all their employees in the park. With this practice, we can make an accurate measurement of the value generated by the specific part of the company that is located in the STP. The only way to have a more precise value, is to use direct and specific accounting data about the business unit located in the park, which is discouraging due to many practical constraints, e.g. limited availability, high quantity of companies to be contacted and a high level of resources needed. To estimate the value generated by a multinational or multi-site company, we assume that the company needs all its units to produce the value it generates in aggregate. On this conceptual basis, the value will be proportional to the number of employees in the park.

\section{Step 2: Data extraction from the ORBIS Platform}

As mentioned above, with the list of VAT numbers we can search the ORBIS database for the companies that make up the STP community. If present in the repository, both the accounting information that allows us to calculate the social value and the contextual information that serves as control and plausibility are extracted for each company. The following table 1 shows the main accounting information and some information used for control. 


\section{Table 1. ORBIS Platform - Financial and Control information}

Financial information

\begin{tabular}{|c|c|c|c|}
\hline $\begin{array}{l}\text { Information/data } \\
\text { ORBIS Nomenclature }\end{array}$ & Purpose & $\begin{array}{l}\text { Information/data } \\
\text { ORBIS Nomenclature }\end{array}$ & Purpose \\
\hline $\begin{array}{l}\text { Sales } \\
\text { th EUR Last avail. yr }\end{array}$ & $\begin{array}{l}\text { Calculation } \\
\text { SV-SIEA customers }\end{array}$ & Company name & $\begin{array}{l}\text { Control and company } \\
\text { identification }\end{array}$ \\
\hline $\begin{array}{l}\text { Added value } \\
\text { th EUR Last avail. yr }\end{array}$ & $\begin{array}{l}\text { Calculation } \\
\text { SV-SIEA suppliers }\end{array}$ & European VAT number & $\begin{array}{l}\text { Company } \\
\text { identification and } \\
\text { tracking }\end{array}$ \\
\hline $\begin{array}{l}\text { Costs of employees } \\
\text { th EUR Last avail. yr }\end{array}$ & $\begin{array}{l}\text { Calculation } \\
\text { SV-SIEA employees and } \\
\text { public administration }\end{array}$ & $\begin{array}{l}\text { NACE Rev. 2, core code } \\
\text { ( } 4 \text { digits) }\end{array}$ & $\begin{array}{l}\text { Cross-check company } \\
\text { and sector }\end{array}$ \\
\hline $\begin{array}{l}\text { Taxation } \\
\text { th EUR Last avail. yr }\end{array}$ & $\begin{array}{l}\text { Calculation } \\
\text { SV-SIEA public } \\
\text { administration }\end{array}$ & Status & $\begin{array}{l}\text { Identification of the } \\
\text { activity status of the } \\
\text { holding (Step } 3 \text { key } \\
\text { information) }\end{array}$ \\
\hline $\begin{array}{l}\mathrm{P} / \mathrm{L} \text { after tax } \\
\text { th EUR Last avail. yr }\end{array}$ & $\begin{array}{l}\text { Calculation } \\
\text { SV-SIEA shareholders }\end{array}$ & $\begin{array}{l}\text { Standardised legal } \\
\text { form }\end{array}$ & $\begin{array}{l}\text { Identification of the } \\
\text { obligation to present } \\
\text { accounts }\end{array}$ \\
\hline $\begin{array}{l}\text { Depreciation \& } \\
\text { Amortization } \\
\text { th EUR Last avail. yr }\end{array}$ & $\begin{array}{l}\text { Calculation } \\
\text { SV-SIEA retention }\end{array}$ & Last avail. year & $\begin{array}{l}\text { Identification of } \\
\text { the accounting } \\
\text { information } \\
\text { obsolescence (Step } 3 \\
\text { key information) }\end{array}$ \\
\hline $\begin{array}{l}\text { Financial expenses } \\
\text { th EUR Last avail. yr }\end{array}$ & $\begin{array}{l}\text { Calculation } \\
\text { SV-SIEA financial } \\
\text { entities }\end{array}$ & $\begin{array}{l}\text { Number of employees } \\
\text { Last avail. yr }\end{array}$ & $\begin{array}{l}\text { Identification of the } \\
\text { organisation size (Step } \\
3 \text { key information) }\end{array}$ \\
\hline $\begin{array}{l}\text { Financial revenue } \\
\text { th EUR Last avail. yr }\end{array}$ & $\begin{array}{l}\text { Calculation } \\
\text { SV-SIEA financial } \\
\text { entities }\end{array}$ & $\begin{array}{l}\text { Capital } \\
\text { th EUR Last avail. yr }\end{array}$ & $\begin{array}{l}\text { Control and } \\
\text { plausibility of the } \\
\text { accounting data }\end{array}$ \\
\hline $\begin{array}{l}\text { Operating revenue } \\
\text { (Turnover) } \\
\text { th EUR Last avail. yr }\end{array}$ & $\begin{array}{l}\text { Calculation and control } \\
\text { SV-SIEA customers }\end{array}$ & $\begin{array}{l}\text { Fixed assets } \\
\text { th EUR Last avail. yr }\end{array}$ & $\begin{array}{l}\text { Control and } \\
\text { plausibility of the } \\
\text { accounting data }\end{array}$ \\
\hline
\end{tabular}

Notes:

th EUR Last avail. yr = thousands of EUROS and last available year

SV-SIEA = Social Value in terms of Social Impact of Economic Activity

Source: Own elaboration based on ORBIS Platform (Bureu Van Dijk - A Moody's Analytics Company).

As shown in the left column (see Table 1), basically eight items have been identified within Balance sheet and Profit loss account that allow us to reconstruct and estimate the social impact of economic activity (SIEA), namely: "sales", "added value", "cost of employees", "taxation", 
"P/L (Profit/Loss) after tax", "depreciation \& amortization", "financial expenses" and "financial revenue". The ninth item, i.e. Operating revenue (Turnover), allows us to cross-check with sales to verify the plausibility of the entire economic situation of the company. The methodological detail on the calculation of the social value is reported in the following subsection.

These items were selected after careful evaluation of all the fields in the different repositories in ORBIS; ultimately choosing to extract the accounting data from the following repository "Financial Data - Global standard format - Corporate - Balance sheet and Profit loss account". The criteria used for the choice of the single items were the degree of compilation by the companies and the usefulness for the derivation of the values for the calculation of the social value for the six main stakeholders, i.e. workers, suppliers, customers, shareholders, financial entities and public administration. In the case of added value and social value (SV-SIEA) for suppliers we can state that the database provides specific fields for the calculation of these values, unfortunately these items have a very low degree of compilation by companies and therefore cannot be used. To overcome this aspect, the decision was to work directly with the item "Value Added" in which companies estimate on their own and declare the generated value and with which according to a specific proxy we can derive the value for suppliers.

It is also important to specify, as indicated in the table above, that for the single accounting items the extracted values are related to the last available accounting year. This choice was made in order to consider a reasonable delay in the discounting of the values by the companies; this will be a criterion phase three: filtering the company population data in order to identify the companies that are relevant for the calculation of the social value (SV-SIEA) of the STP.

The right side of the table shows data points extracted from ORBIS, which constitute the control information related to a company. On one hand these data points identify the company (e.g. Company name; European VAT number), on the other hand they are useful for the selection or exclusion of the company in step three (e.g. Status; Last avail. year; Number of employees) as we will see below. The item "Standardised legal form" indicates the legal name and legal entity; from which we can identify the foundations and associations that do not have the obligation to submit accounts to the commercial register. This explains why the accounts have missing values. Finally, the control items "Capital" and "Fixed assets" serve for a more precise idea of the size of the company and to check the plausibility of the number of employees by comparing it with the indicated amount of payroll.

\section{Step 3: Filtering of the company population data}

Once the initial database has been created with all the information related to the companies that constitute the STP companies community, we move on to the selection phase of the companies that are eligible for the calculation of the social value (SV-SIEA) generated and distributed by the STP. This selection is carried out on the basis of the following criteria: 1) State of company activity 2) Data availability 3) Obsolete data 4) Presence of information on employees established in the STP 5) Completeness of accounting data 6) Data distortion. If these requirements are not met, the companies are excluded from the calculation. This methodolog- 
ical choice is aimed at minimizing the distortion in the stakeholders' value calculation due to partial information. Therefore, it was decided to operate only with the pool of companies that have complete, up-to-date and undistorted accounting data. In other words, we only consider the companies that have the data available to reconstruct and estimate the value generated for the six main stakeholders.

\section{Step 4: Calculation of the social impact of economic activity (SIEA)}

In the fourth and final step, based on a now cleaned-up database, we move on to the actual social value calculation (we will focus on the SIEA part of social value) for all six stakeholders that will be considered in this work: workers, suppliers, customers, shareholders, financial entities and public administration. As mentioned above, before performing the calculation, the accounting values of each individual entity must be adjusted according to the presence of the organisation's personnel in the STP. In other words, we consider the proportion between the number of employees indicated by the STP manager and the number of employees of the company registered in ORBIS (item "Number of employees Last avail. Year"). This is an approximation that allows a clean calculation; in this case, the values are adjusted only when the proportion is less than $100 \%$. It is worth to remind that this methodology, through the use of proxies, leads to the calculation of an approximate value; for the calculation of the exact value, primary data must be used.

Once a clean database with all the accounting values for the single companies in the STP has been set up, it is possible to proceed with the actual calculation of the social impact of economic activity (SIEA) for each company with regard to the six main stakeholders. The aggregate social value (SV-SIEA) of each analysed organisation constitutes the value generated and distributed by the STP. The value obviously considers only that exact pool of companies, since no generalization proxies were used. Therefore, as shown in the following table, using the accounting values from ORBIS Platform we can calculate the social value (SV-SIEA) for each stakeholder. 


\section{Table 2. Social Value Calculation}

\begin{tabular}{|c|c|c|}
\hline Stakeholder & Code $^{1}$ & Calculus / Proxy - Social Value (SV-SIEA) ${ }^{2}$ \\
\hline Customer & SV-C & SV-C = Sales ${ }_{\mathrm{ORBIS}}$ \\
\hline Supplier & SV-S & SV-S $=\left(\right.$ Sales $_{\mathrm{ORBIS}}-$ Value Added $\left._{\mathrm{ORBIS}}\right) * 43 \%$ \\
\hline Public administration & SV-PE & SV-PE = $\sum(0-V A T ;$ O-VAT; O-SSC; E-SSC) + If(O-TAX > 0) \\
\hline VAT & O-VAT & $\begin{array}{l}\text { O-VAT = Value Added } \\
\text { [E.g. } \% \text { \% Spain 21\% and Sweden 25\%] }\end{array}$ \\
\hline $\begin{array}{l}\text { VAT induced } \\
\text { supplier }\end{array}$ & S-VAT & $\begin{array}{l}\text { S-VAT = (SV-S* \%VATDB_National\%) / } 43 * 100 \\
\text { [E.g. \% Spain 21\% and Sweden 25\%] }\end{array}$ \\
\hline $\begin{array}{l}\text { Employer paid } \\
\text { - Social security } \\
\text { contributions }\end{array}$ & $0-55 C$ & $\begin{array}{l}\text { O-SSC = Costs of employees } \\
\text { [E.g. \% Spain } 29.9 \% \text { and Sweden } 31.42 \% \text { ] }\end{array}$ \\
\hline $\begin{array}{l}\text { Employee paid } \\
\text { - Social security } \\
\text { contributions }\end{array}$ & E-SSC & $\begin{array}{l}\text { E-SSC = Costs of employees } \\
\text { [E.g. \% Spain } 6.35 \% \text { and Sweden } 7 \% \text { \% }\end{array}$ \\
\hline Taxation & O-TAX & O-TAX = Taxation ORBIS $_{1}$ \\
\hline Employees & SV-E & $\begin{array}{l}\text { SV-E }=\text { Costs of employees } \\
\% 0-S S C D B \text { ORBIS } \\
\text { \% }\end{array}$ \\
\hline Shareholders & SV-Sh & SV-Sh $=P / L$ after tax ${ }_{\text {ORBIS }}$ \\
\hline Financial entities & SV-FE & SV-FE $=\sum$ ASS (Financial expenses ${ }_{\text {ORBIS }} ;$ Financial revenue ${ }_{\text {ORBIS }}$ \\
\hline Organisation & SV-O & SV-O = Depreciation $\&$ Amortization ORBIS \\
\hline Total SV: & SV-T & SV-T = I (SV-C; SV-S; SV-E, SV-PE, SV-Sh, SV-FE, SV-O) \\
\hline
\end{tabular}

Source: Own elaboration based on (Retolaza et al., 2016a; Retolaza et al., 2016b), data source ORBIS Platform (Bureu Van Dijk - A Moody's Analytics Company).

Table 2 shows the calculation proxies used to estimate the social value (SV-SIEA) for each stakeholder. These proxies were developed through practical application to case studies in different countries, i.e. the Basque Network of STPs in Spain and the Linköping Science Park in Sweden. As a result, the calculations are generalized and can be adapted according to the specifications of the country where the STP is located. Coherently, the decision was to use a common source, i.e. the national Doing Business Report - Comparing Business Regulation in 190 countries by the World Bank Group, to obtain the tax percentages for different countries in a standardized way: Value Added Tax (VAT) and Social Security Contributions (SSC) - used for

1. In this case, with code SV we refer to de social value in terms of social impact of economic activity (i.e. SV-SIEA).

2. The origin of the data is indicated as a subscript: ORBIS if it is an accounting value coming from the ORBIS platform, while DBNational\% if it is a percentage extrapolated from the national specific Doing Business report. 
the calculation of SV-SIEA for employees and partially for public administration. The choice of this source, together with the use of the ORBIS Platform for accounting data, allows the application of the methodology to STPs located in different European countries (and around the world). In this way, it is possible to access standardized information on regulations of 190 countries, and also on accounting data of companies in various countries. In fact, the calculation procedure shown in table 2 can potentially be applied all STPs in Europe.

Specifically, for some stakeholders (i.e. customers, shareholders and the company itself) the SV-SIEA corresponds to the value of the accounting item associated with them: for customers the SV-SIEA corresponds to the sales made by the company (see Sales ${ }_{0 \mathrm{RBIS}}$ ), for shareholders it

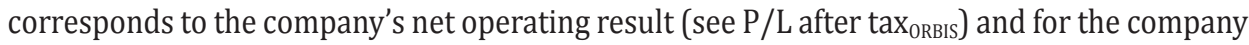
it is the amount of depreciation (see Depreciation \& Amortization $_{\text {ORBIS }}$ ) (Retolaza et al., 2016b). To be precise, the latter value is considered as the SV-SIEA retained by the company, which added to the SV of the other stakeholders constitutes the total SV-SIEA generated and distributed by the company under analysis.

Much different is the calculation for the other four stakeholders (i.e. financial entities, suppliers, public administration, and employees) where the SV-SIEA has to be estimated with the use of a proxy. In the case of the SV-SIEA that benefits financial entities, both the company's financial revenue (see Financial revenue ${ }_{0 \text { RBIS }}$ ) and financial expenses (see Financial expensesORBIS) are added as absolute values, since the financial flows in both directions generate value for the financial institutions.

For the value generated to suppliers, we developed a proxy based on Retolaza et al. (2016a), which assumes that the value generated for suppliers is estimated to be $43 \%$ of the value resulting from the subtraction of the value added generated by the company (see Value AddedORBIS) from the sales made by it (see Sales ${ }_{0 \mathrm{RBI}}$ ). In this case, as mentioned in the previous subsection, we use this proxy because we do not have access to neither data to reconstruct the added value generated by the company nor accounting information on the cost of supplies.

With regard to SV-SIEA generated for the public administration, we would argue that it consists mainly of five elements: the value added tax of the company itself (0-VAT), the value added tax induced to suppliers (S-VAT), the social contributions paid by the company on the wage bill (0-SSC), the social contributions paid by employees (E-SSC) and, finally, the taxes paid by the company (0-TAX). As shown in the table, the total SV-SIEA estimated for the public administration is equal to the sum of the first four elements, plus a fifth element in case of positive value. The reason of this proxy lies in the fact that we are making a timeless analysis and therefore the negative value of taxes due is not discounted from the calculation of the total SV-SIEA for public administration. If, on the other hand, a longitudinal analysis were to be carried out, the carry-over of negative values between the various years of analysis would actually have to be considered.

Please note that for the taxes paid, the reference is the book value declared by the company (see Taxation ${ }_{\text {ORвIS }}$ ). For the calculation of social security contributions, both paid by the company (O-SSC) and paid by employees (E-SSC), the percentage specific to the country where the $\mathrm{STP}$ is established is directly applied, both for the employer (see 0-SSC $\mathrm{DB}_{\mathrm{B}_{-} \text {ational\% }}$ ) and for the 
employees (See E-SSC $\mathrm{DB}_{\mathrm{B}_{\mathrm{N}} \text { ational\% }}$ ) on the wage bill (see Costs of employees ${ }_{\mathrm{ORBIS}}$ ). In contrast, in the case of value added tax paid by the enterprise, the contribution due is calculated directly by applying the national tax rate (see VAT $\mathrm{DB}_{\text {_National\% }}$ ) to the amount of value added declared by

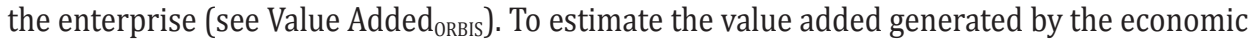
activity with the supply chain we use a proxy based on Retolaza et al. (2015) which assumes a calculation of the value added tax based on the SV-SIEA generated for suppliers (SV-S) through the national tax rate (see $\mathrm{VAT}_{\mathrm{DB}_{\mathrm{B}} \text { ational\%) }}$ ) while reporting the value at $100 \%$ (see Table 2).

Finally, the SV-SIEA generated for employees corresponds, basically, to the wage bill indicated by the company (see Costs of employees ${ }_{0 \mathrm{RBI}}$ ) minus the social security contributions paid by both the employer (0-SSC) and the employees themselves (E-SSC), which are a constituent part of the SV-SIEA generated for the public administration. The table shows the formula for the direct calculation.

In conclusion, this procedure allows to effectively calculate how much social value (SV-SIEA) a single organisation generates and how it distributes the value to stakeholders. Furthermore, the adopted approach allows on one hand the closest approximation in the calculation of the social impact from economic activity (SIEA) with the available secondary data and, on the other hand, it is a suitable methodology for large volumes of data. Technically the data and calculations are managed by means of spreadsheets (E.g. Microsoft Excel Software); this makes it possible to set various control parameters to guarantee the correctness of the analysis and, at the same, it saves time to manage large volumes of data. More precisely - as reported in the section on application cases - in the context of STPs we have performed a simultaneous analysis of several hundred organisations, while our territorial analysis was on a scale of several thousand organisations.

\subsection{Adapting of the SPOLY model procedure to the territorial context}

Unlike the adaptation for the STP context, the one for the territory analysis is designed to work directly and only with secondary data. In this case, the procedure is developed in three steps: 1) Preliminary selection of the companies and data extraction from the ORBIS Platform 2) Secondary filtering of the company population data 3) Calculation of social impact of economic activity (SIEA). In steps 1 and 2 there are some differences if compared to the procedure for STPs, while step 3 corresponds almost exactly to step 4 for STPs. Therefore, the calculation of social impact of economic activity (SIEA) is performed with the same data and in the same way; this allows the comparison of results. Below is a brief description of the three steps, indicating the differences with respect to the STP context. 


\section{Step $1_{\mathrm{T}}$ : Preliminary selection of the companies and data extraction from the ORBIS Platform}

In this case, we carry out a data collection directly on the ORBIS Platform and, using its search and filtering systems, we make a preliminary selection of the organisations located in the reference territory that meet the requirements for the analysis. This selection is based on four criteria: 1) Company location 2) Entity type 3) State of company activity 4) Data availability. These criteria are applied in a sequential and hierarchical way, in order to narrow down the pool of companies that are suitable for the analysis.

Once the selection criteria have been set, it is possible to extrapolate, as in the STP case, both the accounting information that allows to calculate the social value and the context information that serves as a check and plausibility of company data. In this way, the initial database is now ready for the second and final filtering.

\section{Step $\mathrm{Z}_{\mathrm{T}}$ : Secondary filtering of the company population data}

Having already made a preliminary selection directly in ORBIS, in this second step, exactly as for the STP context, the last two filtering criteria are applied, namely: Completeness of accounting data (see STP context - Step 3 - Criterion 5) and Data distortion (see STP context - Step 3 - Criterion 6). Regarding the completeness criterion, in this case the presence of information in the ORBIS field "Number of employees Last avail. Year" is checked, which serves to select only companies that indicate the number of employees from one upwards. This, as shown in the next section, will be used to calculate the hypothetical SV-SIEA per capita generated by the territory. The same information is also available from the STP analysis; therefore, it can be used as a first comparison.

By applying these additional criteria, we obtain a clean database, which is ready for the calculations to estimate the social impact of economic activity (SIEA) of the company's population affiliated to the territory under study.

\section{Step $3_{\mathrm{T}}$ : Calculation of social impact of economic activity (SIEA)}

As seen in the introduction of this subsection, the calculation procedure is technically the same as in step 4 for the context of STPs (see STP context - Step 4). The only notable difference is that it is unfortunately not feasible to carry out a proportional reconstruction of accounting data based on the staff actually operating in the selected company's territory of affiliation. In particular, given the number of organisations analysed and the unavailability of such data in a systematic way for all entities, it is not possible to reconstruct the data in an efficient and effective way. As seen in the following section, on the application on the threes STP of the Basque Network and on the Linköping Science Park, the companies analysed for each reference territory are in the order of thousands. 


\section{Case application, results and discussion $^{3}$}

Following the methodological adaptation of the SPOLY model for an application to the STP context and the related reference territories (see Figure 1), the first application tests were carried out in collaboration with the Basque Network of STPs and the Linköping Science Park. In this first study, it was possible to apply this methodology to four STPs and related territories. This application has allowed to identify some critical aspects, which are to be considered in the understanding and interpretation of these first results for each park and territory. In particular, we highlight the understanding of some values used for comparison such as the social value (SV-SIEA) generated per capita per company, or per employee. In accordance with the management entities of the four STPs, the results of the individual entities analysed will not be presented and the results in aggregate for STPs and territories are anonymised. The next subsections present the application to the four cases with the related results and some first observations.

\section{Figure 1. Procedures for STP and territorial contexts}

\begin{tabular}{|c|c|c|c|c|c|c|}
\hline \multicolumn{4}{|c|}{ Procedure for STP context: } & \multicolumn{3}{|c|}{ Procedure for territorial context: } \\
\hline $\begin{array}{l}\text { Step 1: } \\
\text { Primary data } \rightarrow \\
\text { collection }\end{array}$ & $\begin{array}{l}\text { Step 2: } \\
\text { Data } \\
\text { extraction } \\
\text { from the } \\
\text { ORBIS } \\
\text { platform }\end{array}$ & $\begin{array}{l}\text { Step 3: } \\
\text { Filtering of } \\
\text { the company } \\
\text { population } \\
\text { data }\end{array}$ & $\begin{array}{l}\text { Step 4: } \\
\text { Calculation of } \\
\text { the social } \\
\text { impact of } \\
\text { economic } \\
\text { activity }\end{array}$ & $\begin{array}{c}\text { Step 1T: } \\
\text { Preliminary } \\
\text { selection of the } \\
\text { companies and } \rightarrow \\
\text { data extraction } \\
\text { from the ORBIS } \\
\text { platform }\end{array}$ & $\begin{array}{c}\text { Step 2т: } \\
\text { Secondary } \\
\text { filtering of the } \\
\text { company } \\
\text { population } \\
\text { data }\end{array}$ & $\begin{array}{c}\text { Step 3r: } \\
\text { Calculation of } \\
\text { social impact } \\
\text { of economic } \\
\text { activity (EASI) }\end{array}$ \\
\hline \multicolumn{4}{|c|}{$\begin{array}{l}\text { Notes: } \\
\text { Step 1: Primary data collection } \\
\text { - Data needed: 1) Name of each company at the STP 2) European VAT } \\
\text { identification number 3) Number of employees in the company's } \\
\text { workplace at the STP } \\
\text { Step 3: Filtering of the company population data } \\
\text { - Criteria: 1) State of company activity 2) Data availability 3) Obsolete } \\
\text { data 4) Presence of information on employees established in the STP 5) } \\
\text { Completeness of accounting data 6) Data distortion }\end{array}$} & \multicolumn{3}{|c|}{$\begin{array}{l}\text { Notes: } \\
\text { Step 1T: Preliminary selection of the companies and data } \\
\text { extraction from the ORBIS platform } \\
\text { - Criteria: 1) Company location 2) Entity type 3) State of } \\
\text { company activity } 4 \text { ) Data availability } \\
\text { Step } 2 \mathrm{~T} \text { : Secondary filtering of the company population } \\
\text { data } \\
\text { - Criteria: 1) Completeness of accounting data 2) Data } \\
\text { distortion }\end{array}$} \\
\hline
\end{tabular}

Source: Own elaboration.

3. All the financial data used for the application of the methodology, in particular for calculations, are extracted from ORBIS Platform (Companies Financial Database - Bureu Van Dijk - A Moody's Analytics Company). 


\subsection{Case application}

Exactly as foreseen by the procedure, described in the previous section, the first step was the primary data collection. That is, for each STP we were provided of the lists with the companies' names, VAT numbers and number of employees present at the STP workplace. As a result, each STP manager has extracted from the respective facility's database a list of the companies that were established in the park as of 31.12.2018. We observed that within the population of companies analysed in the four cases we had a percentage of data updated to 2018 ranging from $89 \%$ to $100 \%$. Completing the consideration, we are aware that for some cases, i.e. less than $10 \%$, there is a potential deviation in values due to the information collection that may come from different periods (e.g. ORBIS Platform last available year) and from different data collection systems (e.g. internal park questionnaires). In general, however, this does not have a significant impact on the results.

In reconstructing the list of primary data, our experience suggests that connecting names to VAT numbers does not give particular problems; on the other hand, the reconstruction of the employees' number associated with the specific company generates some difficulties. These complications are due in particular to the need to cross-reference information from different databases. This can lead to the generation of incomplete initial lists, which, in a kind of chain reaction, lead to a reduction in the population of potentially analysable companies. As can be seen from the table 3 below, it appears that, compared to the total number of STP companies, there is a loss of analysable entities between $1 \%$ and $8 \%$ due to the lack of information relating to the VAT number and with regard to information on the number of employees there is a loss in the range from $7 \%$ to $33 \%$. This partly explains why at the end of step 3 of the procedure we work with about $50 \%$ of the companies that make up the STP communities. As already mentioned, this problem can easily be managed with direct collection of information.

\section{Table 3. STP Database Creation}

\begin{tabular}{|c|c|c|c|c|c|c|c|c|c|c|c|c|}
\hline & \multicolumn{3}{|c|}{ STP 1} & \multicolumn{3}{|c|}{ STP 2} & \multicolumn{3}{|c|}{ STP 3} & \multicolumn{3}{|c|}{ STP 4} \\
\hline & \begin{tabular}{|c|} 
Nr. \\
Firms
\end{tabular} & $\%$ & $\begin{array}{c}\text { Nr. } \\
\text { Workers }\end{array}$ & $\begin{array}{c}\text { Nr. } \\
\text { Firms }\end{array}$ & $\%$ & $\begin{array}{c}\text { Nr. } \\
\text { Workers }\end{array}$ & $\begin{array}{c}\text { Nr. } \\
\text { Firms }\end{array}$ & $\%$ & \begin{tabular}{c|} 
Nr. \\
Worke
\end{tabular} & \begin{tabular}{|c|} 
Nr. \\
Firms
\end{tabular} & $\%$ & $\begin{array}{c}\text { Nr. } \\
\text { Workers }\end{array}$ \\
\hline Companies Names & 266 & $100 \%$ & & 141 & $100 \%$ & & 144 & $100 \%$ & & 367 & $100 \%$ & \\
\hline Compa & 245 & $92 \%$ & & 138 & $98 \%$ & & 143 & $99 \%$ & & 352 & $96 \%$ & \\
\hline Com & 191 & $78 \%$ & $11 ' 100$ & 109 & $79 \%$ & 5 '092 & 97 & $68 \%$ & 3'357 & 341 & $97 \%$ & 6304 \\
\hline ORBIS - VAT Numbers Searched & 245 & $100 \%$ & & 138 & $100 \%$ & & 143 & $100 \%$ & & 352 & $100 \%$ & \\
\hline ORBIS - VAT Numbers Found & 234 & $96 \%$ & & 133 & $96 \%$ & & 141 & $99 \%$ & & 352 & $100 \%$ & \\
\hline & 1 & $86 \%$ & & 125 & $91 \%$ & & 139 & $97 \%$ & & 339 & $96 \%$ & \\
\hline Dat & 179 & $73 \%$ & & 100 & $72 \%$ & & 105 & $73 \%$ & & 336 & $95 \%$ & \\
\hline Data up-to-date $>2016$ & 173 & $71 \%$ & & 90 & $65 \%$ & & 100 & $70 \%$ & & 330 & $94 \%$ & \\
\hline Com & 138 & $56 \%$ & 034 & 72 & $52 \%$ & $22^{\prime} 672$ & 63 & $44 \%$ & & 255 & $72 \%$ & $6^{\prime} 078$ \\
\hline & 32 & $54 \%$ & 588 & 69 & $50 \%$ & & 62 & $43 \%$ & & 108 & $31 \%$ & \\
\hline Data without distortion & 124 & $51 \%$ & $7 ' 290$ & 62 & $45 \%$ & \begin{tabular}{|l|l}
$2^{\prime} 608$ \\
\end{tabular} & 53 & $37 \%$ & \begin{tabular}{|l|l|}
$2^{\prime}$ \\
\end{tabular} & \begin{tabular}{|l|l|}
107 & \\
\end{tabular} & $30 \%$ & $\begin{array}{l}3^{\prime} 084 \\
\end{array}$ \\
\hline
\end{tabular}

Source: Own elaboration based on data source ORBIS Platform (Bureu Van Dijk - A Moody's Analytics Company) and (World Bank Group, 2020a, 2020b). 
Once the data and information relating to the companies identified by the VAT number have been extracted from ORBIS, step 2 of the procedure is considered completed and we move on to step 3 , the filtering of the company population data. In this case, the companies are selected according to the six criteria illustrated in the previous section: 1) State of company activity 2) Data availability 3) Obsolete data 4) Presence of information on employees established in the STP 5) Completeness of accounting data 6) Data distortion.

As can be seen from the table 3, with regard to the first criterion, we note that between $86 \%$ and $96 \%$ of the entities are selected. In this case, we have a loss of information ranging from $2 \%$ to $10 \%$, therefore relatively small. Some of these cases are linked to the change of name of some companies in the park or the closure and opening of companies linked to the same corporate group.

Turning to the second criterion, related to data availability, we have a loss of information ranging from $1 \%$ in the best case to $24 \%$ in the worst case. This loss of information is sometimes linked to the strong presence of foundations, associations and non-profit organisations, which under certain conditions are not obliged to publish their accounts. Therefore, ORBIS lists the entity but the items in the accounts are empty. In particular, in the context of STPs, these are mostly organisations active in the field of research under the legal form of non-forprofit foundations.

Under the third criterion, data obsolescence, we find that only between $1 \%$ and $7 \%$ of the organisations in the four STPs do not have updated data; in our case this means data after the year 2016. This suggests that, by having primary data on an annual basis, it is possible to apply the same methodology for a possible longitudinal study, i.e. considering the analysis of the evolution over a precise period.

On the other hand, considering the fourth criterion, i.e. the presence of primary information on company workforce in the STP, we observe an important reduction of the entities eligible for the analysis. Specifically, we have a percentage ranging from $13 \%$, in the best case, to $26 \%$, in the worst case, of companies that are not considered for the analysis. It should be noted that, for one of the cases, an important number of organisations was excluded because they had zero employees. While, in another case, within the STP we found a large presence of company groups, for which the aggregate figure of all companies was indicated under the VAT number of the parent company. In those cases, we set a proxy by considering the aggregate of the group (with all its respective companies) and by calculating the relevant proportion. Therefore, the final number of cases analysed for some STPs actually corresponds to a higher number of companies than indicated. However, the result obtained for the generated and distributed SV-SIEA is correctly proportionate with respect to the number of employees indicated by the company groups. With an outlook to future applications of the methodology, even these two aspects can be easily overcome with a completion and verification of the primary list of data.

Considering the criteria five and six, we note that for the fifth criterion, relating to the completeness of accounting data, we have a loss of companies of about $2 \%$ and for the sixth criterion, relating to data distortion, we have a maximum loss of $6 \%$. Among the STPs there is a particular case, where we observe, for the criterion of completeness of accounting data, a loss 
of analysable entities of $42 \%$, largely due to lack of information on added value. However, there is no loss due to data distortion.

At the end of this procedure, four clean databases were created to calculate the social impact of economic activity (SIEA) with 346 organisations employing 15,330 people in the four STPs.

With regard to the reference territories of the STPs (see Table 4), the adopted procedure was the one explained in subsection 2.2. As a result of the selection process we have a population of companies that can be analysed in the range of 14\%-18\% compared to all the entities registered in the territories; that is, between four thousand and fourteen thousand companies considering each territory.

\section{Table 4. Territories Database Creation}

\begin{tabular}{|c|c|c|c|c|c|c|c|c|c|c|c|c|}
\hline & \multicolumn{3}{|c|}{ STP's Territory 1} & \multicolumn{3}{|c|}{ STP's Territory 2} & \multicolumn{3}{|c|}{ STP's Territory 3} & \multicolumn{3}{|c|}{ STP's Territory 4} \\
\hline & $\begin{array}{c}\text { Nr. } \\
\text { Firms }\end{array}$ & $\%$ & $\begin{array}{c}\text { Nr. } \\
\text { Workers }\end{array}$ & $\begin{array}{l}\text { Nr. } \\
\text { Firms }\end{array}$ & $\%$ & $\begin{array}{c}\text { Nr. } \\
\text { Workers }\end{array}$ & $\begin{array}{c}\text { Nr. } \\
\text { Firms }\end{array}$ & $\%$ & $\begin{array}{c}\text { Nr. } \\
\text { Worker } \\
\text { s }\end{array}$ & $\begin{array}{c}\text { Nr. } \\
\text { Firms }\end{array}$ & $\%$ & $\begin{array}{c}\text { Nr. } \\
\text { Workers }\end{array}$ \\
\hline ORBIS & $101^{\prime} 086$ & $100 \%$ & & $66^{\prime} 183$ & $100 \%$ & & $29^{\prime} 168$ & $100 \%$ & & $77^{\prime} 397$ & $100 \%$ & \\
\hline Corp. and Found./Research institute & $98^{\prime} 198$ & $97 \%$ & & $64^{\prime} 929$ & $98 \%$ & & $28^{\prime} 002$ & $96 \%$ & & $75^{\prime} 762$ & $98 \%$ & \\
\hline Active companies & $67^{\prime} 677$ & $67 \%$ & & $49^{\prime} 893$ & $75 \%$ & & $20^{\prime} 931$ & $72 \%$ & & $60^{\prime} 919$ & $79 \%$ & \\
\hline Data available and up-to-date $>2016$ & $19 ' 539$ & $19 \%$ & & $12 ' 854$ & $19 \%$ & & $5^{\prime} 625$ & $19 \%$ & & $52^{\prime} 189$ & $67 \%$ & \\
\hline Companies with Nr. workers & $14^{\prime} 098$ & $14 \%$ & $395 ' 682$ & $10^{\prime} 167$ & $15 \%$ & $198^{\prime} 946$ & $4 ' 263$ & $15 \%$ & $74^{\prime} 455$ & $14^{\prime} 058$ & $18 \%$ & $181 ' 364$ \\
\hline Complete accountig data & $13^{\prime} 696$ & $14 \%$ & $340^{\prime} 707$ & $9^{\prime} 909$ & $15 \%$ & $197 ' 647$ & 4'137 & $14 \%$ & $67^{\prime} 609$ & $4^{\prime} 045$ & $5 \%$ & $93^{\prime} 224$ \\
\hline Data without distortion & 13'157 & $13 \%$ & $332 ' 822$ & 9'555 & $14 \%$ & $192 ' 145$ & 3'952 & $14 \%$ & $66^{\prime} 084$ & $3 ' 945$ & $5 \%$ & $92 ' 785$ \\
\hline
\end{tabular}

Source: Own elaboration based on data source ORBIS Platform (Bureu Van Dijk - A Moody's Analytics Company) and (World Bank Group, 2020a, 2020b).

The table 4 indicates, for each territory the number of eligible organisations with respect to the criteria of step one (i.e. 1) Company location 2) Entity type 3) State of company activity 4) Data availability) and step two (i.e. Completeness of accounting data; Data distortion).

As shown in the table, through the first criterion we collect from ORBIS all the companies registered with the NUTS3 code corresponding to the analysed territory. This first selection gives us the pool of companies from which to choose those that can be analysed. Therefore, by applying the second filter related to the type of company we have a minimum reduction of the pool in the range between $2 \%$ and $4 \%$. With the third criterion, i.e. considering only active companies, we have a further reduction ranging from $19 \%$ to $30 \%$ of the organisations that can be analysed. With regard to the fourth criterion, i.e. the data availability, we observe two distinct phenomena. In one case, we have a relatively small reduction in the pool, around $11 \%$. In other words, $67 \%$ of organisations have data up-to-date information as of 2016 . In the other three cases, we have quite the opposite phenomenon; we have a reduction of the pool in the range from $48 \%$ to $56 \%$. Only about $20 \%$ of the companies registered in those territories have their accounting data updated in ORBIS.

As far as the selection criteria of step 2 are concerned, initially we first selected only those companies that we had information related to personnel. With this filter, we can observe on one case an exclusion of $49 \%$ of the companies, while for the other cases it is around $5 \%$. In 
the territory where such an important reduction can be noticed, there is also a further $13 \%$ reduction based on the criterion of completeness of data. In the other three cases, the reduction is almost zero. With this experience, we have observed that in some cases the overwhelming selection of organisations is made at the level of data availability and at the level of completeness. In some cases, there are not many companies with the information that is up to date, but most of them have the key data to be considered for the analysis. In other cases, there are many companies with information that is up to date but, unfortunately, only a minor part meets the completeness requirement for the application of the calculation.

Finally, with regard to the last criterion, the exclusion of organisations is practically negligible. The companies selected for the analysis of the territory range from a minimum of $5 \%$ to a maximum of $14 \%$ of the enterprises registered in the territory. If we compare the number of enterprises selected for the calculation of social value (SV-SIEA) with the number of enterprises with data that is up to date as of 2016 (i.e. operative entities), the quantity for the three cases without data distortion (due to incomplete data) is of about $70 \%$ of the population of the operative enterprises.

With this selection procedure, four clean databases have been created for the territories on which the calculations of the social impact of economic activity (SIEA) will be carried out, which means an analysis of 30,609 organisations employing a total of about 700,000 people.

The next subsection presents the results obtained with the last step of the monetisation of social value (SV-SIEA).

\subsection{Results and discussion}

Following the application of the calculation, illustrated in section 2.1, we obtain the results shown below in table 5. For each of the four cases we have the results for both the STPs and the reference territories. In the upper part of the table, as a first value we can observe the monetisation of the generated social value (SV-SIEA) measured in thousands of euros. Downwards we can observe the quantity of organisations used for the calculation and the related number of employees. These last two pieces of information are used to calculate the first parameters for comparison, i.e. the SV-SIEA per capita per company and the SV-SIEA per capita per employee. In the lower part of the table, we can see how it is distributed, both in thousands of euros and in percentage, among the main stakeholders (i.e. workers, suppliers, customers, shareholders, financial entities and public administration) and how much of it remains in the company. It is important to remember that the absolute values obtained with this analysis are generated by only some of the companies that populate the STP; for example, the value generated by non-profit research centres is not included. Therefore, we can say that this is a first value to get an idea of how much value a STP generates and, above all, how it distributes the value among the main stakeholders. The value of the whole STP would be higher than what is monetised in table 5, if all organizations stablished in the parks could be taken into account through secondary data. 


\section{Table 5. Social Value creates and distributed by STP and reference territory}

\begin{tabular}{|c|c|c|c|c|c|c|c|c|}
\hline \multirow{2}{*}{ Values in Thousands Euros } & \multicolumn{2}{|c|}{ Case 1} & \multicolumn{2}{|c|}{ Case 2} & \multicolumn{2}{|c|}{ Case 3} & \multicolumn{2}{|c|}{ Case 4} \\
\hline & STP & Territory & STP & Territory & STP & Territory & STP & Territory \\
\hline Aggregated Social Value & $3^{\prime} 681^{\prime} 105$ & $164^{\prime} 106^{\prime} 613$ & $864^{\prime} 974$ & 69'276'203 & 832299 & $27^{\prime} 435^{\prime} 002$ & $1^{\prime \prime 251 ' 680}$ & $40^{\prime} 849^{\prime} 401$ \\
\hline Number of Companies & 124 & $13 ' 157$ & 62 & 9'555 & 53 & 3'952 & 107 & $3^{\prime} 945$ \\
\hline Number of Workers & 7290 & 332 ' 822 & $2^{\prime} 608$ & $192 ' 145$ & $2^{\prime} 348$ & $66^{\prime} 084$ & $3^{\prime} 084$ & $92 ' 785$ \\
\hline Social Value per Worker & 505 & 493 & 332 & 361 & 354 & 415 & 406 & 440 \\
\hline Social Value per Company & $29^{\prime} 686$ & $12^{\prime} 473$ & $13^{\prime} 951$ & 7250 & $15^{\prime} 704$ & 6'942 & $11^{\prime} 698$ & $10^{\prime} 355$ \\
\hline Distibution in value: & & & & & & & & \\
\hline Customers & 1'971'357 & $90 \prime 874 ' 614$ & $452^{\prime} 054$ & $38^{\prime} 009^{\prime} 589$ & $442^{\prime} 708$ & $15^{\prime} 048^{\prime} 272$ & $632 ' 739$ & $22^{\prime} 193^{\prime} 319$ \\
\hline Suppliers & $523^{\prime} 075$ & $29^{\prime} 881^{\prime} 324$ & $110^{\prime} 631$ & $11^{\prime} 384^{\prime} 986$ & $127 ' 446$ & $4^{\prime} 644^{\prime} 947$ & $1366^{\prime} 661$ & $6^{\prime} 253^{\prime} 783$ \\
\hline Workers & $230^{\prime} 007$ & $7^{\prime} 865^{\prime} 348$ & $77 ' 851$ & 4'931'002 & $61 ' 863$ & $1^{\prime} 752^{\prime} 631$ & $133^{\prime} 085$ & $2^{\prime} 503^{\prime} 947$ \\
\hline Public Administration & $568^{\prime} 292$ & $244^{\prime} 694^{\prime} 054$ & $145 ' 506$ & $11^{\prime} 161^{\prime} 119$ & $147^{\prime} 449$ & $4^{\prime} 434^{\prime} 221$ & $248^{\prime} 632$ & 7'948'806 \\
\hline Company Reteined & $193^{\prime} 011$ & 3'216'773 & $30^{\prime} 850$ & $1^{\prime} 503 ' 036$ & $23^{\prime} 748$ & $602 ' 210$ & $28 ' 786$ & $686 ' 779$ \\
\hline Shareholder & $121^{\prime} 333$ & $3^{\prime} 670^{\prime} 360$ & $34: 482$ & $1^{\prime} 443^{\prime} 125$ & $12^{\prime} 796$ & $503^{\prime} 330$ & $59^{\prime} 953$ & 1'044'418 \\
\hline Financial Entities & $74^{\prime} 031$ & 3'904'140 & $13 ' 599$ & $843^{\prime} 345$ & $16 ' 289$ & 449 '391 & $11 ' 824$ & $218^{\prime} 349$ \\
\hline $\begin{array}{l}\text { Distribution in percentage: } \\
\text { Customers }\end{array}$ & $53.55 \%$ & $55.38 \%$ & $52.26 \%$ & $54.87 \%$ & $53.19 \%$ & $54.85 \%$ & $50.55 \%$ & $54.33 \%$ \\
\hline Suppliers & $14.21 \%$ & $18.21 \%$ & $12.79 \%$ & $16.43 \%$ & $15.31 \%$ & $16.93 \%$ & $10.92 \%$ & $15.31 \%$ \\
\hline Workers & $6.25 \%$ & $4.79 \%$ & $9.00 \%$ & $7.12 \%$ & $7.43 \%$ & $6.39 \%$ & $10.63 \%$ & $6.13 \%$ \\
\hline Public Admin. & $15.44 \%$ & $15.05 \%$ & $16.82 \%$ & $16.11 \%$ & $17.72 \%$ & $16.16 \%$ & $19.86 \%$ & $19.46 \%$ \\
\hline Company Reteined & $5.24 \%$ & $1.96 \%$ & $3.57 \%$ & $2.17 \%$ & $2.85 \%$ & $2.20 \%$ & $2.30 \%$ & $1.68 \%$ \\
\hline Shareholder & $3.30 \%$ & $2.24 \%$ & $3.99 \%$ & $2.08 \%$ & $1.54 \%$ & $1.83 \%$ & $4.79 \%$ & $2.56 \%$ \\
\hline Financial Entities & $2.01 \%$ & $2.38 \%$ & $1.57 \%$ & $1.22 \%$ & $1.96 \%$ & $1.64 \%$ & $0.94 \%$ & $0.53 \%$ \\
\hline
\end{tabular}

Source: Own elaboration based on data source ORBIS Platform (Bureu Van Dijk - A Moody's Analytics Company) and (World Bank Group, 2020a, 2020b).

For these four cases, the social impact from economic activity (SIEA) of STPs ranges from 800 million euros in case of small parks to over 1 and 3 billion in case of large parks, as shown in the table. This leads us, with due caution, to estimate the generation of value per employee to be between 330 and 500 thousand euros and the generation of value for each company to be between 7 and 29 billion euros. By comparison, the values for the territories range from 350 to 490 thousand euros for each employee and from 7 to 12 billion euros for each company. In general, it should be noted that the value per company tends to be higher in the STPs (i.e. SV-SIEA per Company). At the same time, we have to notice that the STP's value per capita (i.e. SV-SIEA per Employee) are in line with their territory. We would like to remind that, in the case of STPs, these values are based on a portion of their total community and that, in the case of the territories, no proportion was considered to weigh the actual employees on a geographical basis.

of greater interest is the distribution of this value among the stakeholders. In our analysis, we can notice a common behaviour in STPs: STPs tend to re-distribute more value to stakeholders such as workers and shareholders; STPs also show a higher retention of value within the company and proportionally distribute less value to suppliers and public administration. As far as financial entities are concerned, there is no clear trend. These aspects are certainly worthy of further analysis. In this case, we will not go much further into discussing the results, because they go beyond our initial objective. 
By applying this methodology and following the procedure, we obtain a database for each STP and its respective territory that allows to make multiple analyses - for example, it is possible to make analyses related to the SV-SIEA generated and distributed according to the size of the companies. From our experience, we can conclude that the methodology is flexible and handy for a whole series of analyses with precise figures. As far as the ORBIS Platform is concerned, we can say that it has proved to be a valid source for data collection and that it can be strategic for an extension of the study at a European level. In addition, for specific analysis on the STP's community of companies, the ORBIS Platform is well suited to find further information - such as the NACE code of the companies that makes it possible to identify the field of activity for subsequent analysis on the creation and distribution of value with respect to possible clusters of companies within the STP.

With regard to the business community of the STP, its composition in terms of type of companies (e.g. start-ups and spin-offs that do not yet have an accounting history; foundations that are not obliged to file financial statements; large corporate groups that have different systems of presenting information, etc.) is a factor that may influence the number of entities after the selection process considered in the analysis. It can also be a key element to be considered at the time of analysis and interpretation of the obtained values. In this perspective the rate of exclusion of companies can be reduced considerably on one hand by improving the completeness of the initial data (note that the STPs that made themselves available for this study were not asked to do any work on their databases) and on the other hand by evaluating the possibility of collecting some primary data to complete the accounting information. However, even working only with the secondary data available we can make precise calculations. This allows to work with several STPs simultaneously and in a non-disturbing and non-interfering way towards STP managers and companies.

For coherency, it must be stated that the analysis could also be completed with the remaining three areas of analysis (i.e. the socio-economic return (S-ER), the specific social value (SSV), and emotional value (Retolaza et al., 2016a)), but this is feasible, as already discussed, only with the full involvement of the organisations under analysis. However, what has been done in this study is to develop a methodology to calculate the best approximation of SV-SIEA with the available secondary data. If companies implemented social accounting individually, on one hand the calculation of the social impact of economic activity (SIEA) could be enhanced and, on the other hand, the other three areas of analysis of the SV (i.e. S-ER, SSV and emotional value) could be incorporated in a synergic way. The thoughts of some far-sighted STP managers are moving in this direction, and some first experiments at the level of the entity that manages the STP are being evaluated.

Indeed, having this type of information and being able to carry out certain analyses, makes possible for the STP management to take strategic decisions (e.g. development strategies, positioning strategies, etc.) or to support key decisions towards stakeholders (e.g. public funding bodies, local and regional authorities, etc.). As already discussed in the introduction, the issue of STP performance measurement is an important topic both for practitioners and policy makers as well as for the communities in which they operate. Therefore, also for the stakeholders 
themselves considered in the analysis, it might be of interest to have the information about the generated and distributed SV-SIEA. The monetised values can serve as a complement towards other indicators (e.g. R\&D funding, number of licenses deposited, number of jobs created, etc.) in order to obtain a more complete picture of the overall performance of the STP. In this perspective, with our work we have made a small contribution in terms of monetary quantification with a social meaning, in this case, by measuring the contribution to the main stakeholders. In this respect, it would be interesting for single stakeholders to compare the generated value with their degree of involvement in the activities of the STP as well as in the governance and management of the STP.

\section{Conclusion}

Science and Technology Parks were created at the European level with the aim of making a positive contribution towards economic development, mainly at the regional level. Due to this aim, many regional governments around the world, and especially in the European Union and the United Kingdom, invested in the creation of these technological infrastructures, giving them the legal form of foundations, without the objective of seeking for profits. For the last decades, STPs have worked as incubators for new economic sectors and have generated new jobs and new companies. In fact, these variables (number of jobs and new companies) have been the basic indicators in order to measure the level of success of STPs.

As part of the objectives of the paper, we present a methodology for calculating social value (SV-SIEA) that includes some innovations in comparison with the traditional methodology. Instead of relying on primary data obtained from interviews or consultations made with stakeholders, we propose the use of secondary data in order to calculate the social value (SV-SIEA) generated by an organization. Specifically, information and data are not requested directly to the organisations analysed (i.e. STP community), but the park management body provides the primary data relating to the organisations (i.e. company name, company VAT number and number of employees at the workplace located in the STP) necessary for the application of the methodology. We consider this information as primary because it is not directly accessible by us personally. Thanks to this initial data, we have the essential information to retrieve from specific databases (i.e. ORBIS Platform) all needed secondary data and to develop analyses and calculations on secondary data. In fact, with three key pieces of information we can independently reconstruct the SV-SIEA. We are aware that with this procedure, we can monetise an approximation of the SV-SIEA. In order to complete the analysis with the other three areas (i.e. the socio-economic return (S-ER), the specific social value (SSV) and emotional value), it is necessary to apply the SPOLY model in its traditional form Following with the objectives of the paper, policy makers and practitioners could make use of these results in order to understand the value generated by STPs and its distribution among stakeholders. This information could be used internally in order to take management decisions, and/or externally, in order to be shared with all stakeholders. 
In the case of this paper, we propose the use of secondary information available in databases such as ORBIS and "doing business" to calculate the social value (SV-SIEA) generated by four European STPs and the way this social value is distributed among their stakeholders. These STPs are the three STP belonging to the Basque Network of STPs (Basque Country, Spain), and the Linköping Science Park (Östergötland, Sweden), which are all members of the International Association of Science Parks (IASP). The calculation of SV-SIEA in the field of STPs and its territorial comparison using this new methodology is also a contribution to the academic literature that studies how to measure the social contribution of STPs. In addition, doing this contrast we answer the hypothesis of the paper. After this measurement, the social value (VS-SIEA) per employee and per company in each of the 4 cases was compared twice: in each STP and in each of the 4 reference territories. The results indicate that the value (SV-SIEA) per company is clearly higher in the STPs compared to their respective territories. However, the results are mixed when comparing the value (SV-SIEA) per employee. In this case, only in one of the four STPs does this value exceed the value of the reference territory. Therefore, the initial hypothesis of this paper is only partially fulfilled.

In comparison with the traditional methodology of calculating social value based on the compilation of primary data, the use of secondary data allows the measurement of social value (SV-SIEA) for a bigger number of institutions using less initial inputs in terms of resources needed to gather the information necessary for the calculation of social value. In this way, we have proceeded with the calculation of the social value (SV-SIEA) generated in the aforementioned four STPs using secondary data.

Following this path, we have accomplished the objectives of the paper. In the first place, we have presented the new methodology to calculate social value, based mainly on secondary data. Secondly, we have applied this new methodology to the case of four STPs, with hundreds of corporations and institutions working inside them. In addition, we have applied the measurement of social value (SV-SIEA) not only to individual corporations, or to STPs, but also to subnational territorial entities (the three provinces of the Basque Autonomous Community, and one region in Sweden). The calculation of social value (SV-SIEA) for territorial entities or large groups of corporations would have been almost impossible with a calculation method based on primary data. However, the use of secondary data to calculate social value (SV-SIEA) makes possible the measurement of social value for large groups of corporations (clusters, sectors, or STPs, for example), and also regions, countries or even larger political units, such as the European Union.

However, this new methodology has certain limits. We have to consider the issue related to the obsolescence of the data present in the databases and, in the specific case of territorial analysis, the fact that at the moment no appropriate database (or a generalizable method) has been identified to systematically retrieve the information necessary to carry out a proportion of the social value (SV-SIEA) generated in the region (i.e. number of active workers in the region under analysis). In the case of data obsolescence, the fact of working over a period of three years compared to the single accounting year reduces the effect of this limit while guaranteeing a reasonable result. In general, if there is no availability of secondary data, or if databases 
containing secondary data are of poor quality, then the calculation of social value (SV-SIEA) based on those sources would not be very accurate. In international databases sometimes values are influenced by national legislations or national accounting rules, making comparisons more complicated. On the other hand, databases generated by multinational institutions such as the OECD, the World Bank, the IMF, the United Nations, or the European Union may provide a good starting point for this new methodology based on secondary data. In fact, new research in this area could be done at the regional level for the whole European Union and United Kingdom, for example, in order to assess the generation and distribution of social value (SV-SIEA) of STPs at the European level, in comparison with the regional values. Finally, the possibility of carrying out a second study about the same STPs (or only one of them) using primary data (i.e. collected directly to the companies that constitute the STP community) to calculate the social value (SV-SIAE) generated and distributed by the STP could provide a comparative value between the use of primary and secondary data. In this case, it would be possible to estimate not only the social impact of economic activity (SIEA) but also to calculate the other three areas of analysis (i.e. S-ER, SSV and emotional value).

\section{Acknowledgments}

We would like to thank the management entity of the Basque Network of STPs and Linköping Science Park for their contribution to the development of this research work.

\section{References}

ALCANIZ, L., AGUADO, R., \& RETOLAZA, J.L. (2020): “New business models: Beyond the shareholder approach", Revista Brasileira de Gestao de Negocios, 22, 48-64; DOI: 10.7819/rbgn. v22i1.4035.

AGUADO, R. (2007): Economía y política de la innovación empresarial. El caso de la Red Vasca de Parques Tecnológicos.

AGUADO, R., \& EIZAGUIRRE, A. (2020): "Virtuous Cycles in Humanistic Management", Contributions to Management Science, Springer, Cham. D0I: 10.1007/978-3-030-29426-7.

AGUADO, R., RETOLAZA, J.L., \& ALCAÑIZ, L. (2019): "Action Research Training Experience (ARTE) para la formación de directivos", In Eizaguirre, A., Bezanilla M. J., Arantza, a., \& Sáenz Bilbao, n. (Eds.), Espacios de aprendizaje en Educación Superior, 187-198.

AGUADO R., RETOLAZA J.L. (2020): "Humanistic Management in the Corporation: From Self-Interest to Dignity and Well-being". In: Aguado R., Eizaguirre A. (eds) Virtuous Cycles in Humanistic Management. Contributions to Management Science. Springer, Cham. DOI: 10.1007/9783-030-29426-7_9 
ALBAHARI, A., KLOFSTEN, M., \& RUBIO-ROMERO, J. C. (2019): "Science and Technology Parks: a study of value creation for park tenants", Journal of Technology Transfer, 44(4), 1256-1272, DOI: 10.1007/s10961-018-9661-9.

ALBAHARI, A., PÉREZ-CANTO, S., BARGE-GIL, A. \& MODREGO, A. (2017): “Technology Parks versus Science Parks: Does the university make the difference?", Technological Forecasting and Social Change, 116, 13-28. D0I: 10.1016/j.techfore.2016.11.012.

AYUSO, S., SÁNCHEZ, P., RETOLAZA, J.L. \& FIGUERAS-MAZ, M. (2020): "Social value analysis: the case of Pompeu Fabra University", Sustainability Accounting, Management and Policy Journal, 11(1), 233-252, DOI: 10.1108/SAMPJ-11-2018-0307.

ETZKOWITZ, H. \& ZHOU, C. (2018): "Innovation incommensurability and the science park", R\&D Management, 48(1), 73-87, DOI : 10.1111/radm.12266.

FREEMAN, R.E. (1984): "Strategic management: A stakeholder theory", Journal of Management Studies, 39(1), 1-21.

FREEMAN, R.E., HARRISON, J.S., WICKS, A.C., PARMAR, B.L. \& DE COLLE, S. (2010): Stakeholder theory: The state of the art, Cambridge University Press.

FULGENCIO, H. (2017): "Social value of an innovation ecosystem: the case of Leiden Bioscience Park, The Netherlands", International Journal of Innovation Science, 9(4), 355-373. DOI: 10.1108/IJIS-09-2017-0098.

GONZALO, J.A. \& PEREZ, J. (2017): “Una propuesta de normalización relativa al valor añadido como medida alternativa de rendimiento empresarial", Especial XIX Congreso Internacional AECA, 35-39.

GRAY, R.H. (1994): "Social end environmental accounting, accountability and reporting: New wine in old skins or silk purses from sows' ears?", Acconting Forum: Social and Environmental Accounting, 4-30.

GUADIX, J., CARRILLO-CASTRILLO, J., ONIEVA, L. \& NAVASCUÉS, J. (2016): "Success variables in science and technology parks", Journal of Business Research, 69(11), 4870-4875, DOI: 10.1016/j.jbusres.2016.04.045

HOBBS, K.G., LINK, A.N. \& SCOTT, J.T. (2017): "Science and technology parks: an annotated and analytical literature review", The Journal of Technology Transfer, 42(4), 957-976. D0I: 10.1007/s10961-016-9522-3.

LAZCANO, L., SAN-JOSE, L. \& RETOLAZA, J.-L. (2019): "Social Accounting in the Social Economy: A Case Study of Monetizing Social Value", In: Modernization and Accountability in the Social Economy Sector, 132-150, DOI: 10.4018/978-1-5225-8482-7.ch008. 
LECLUYSE, L., KNOCKAERT, M. \& SPITHOVEN, A. (2019): "The contribution of science parks: a literature review and future research agenda", Journal of Technology Transfer, 44(2), 559-595, DOI: 10.1007/s10961-018-09712-x.

LYRA, R.M.M. \& ALMEIDA, M.F.L. (2018): "Measuring the performance of Science and Technology Parks: a proposal of a multidimensional model", Journal of Physics: Conference Series, 1044, 1-7, DOI: 10.1088/1742-6596/1044/1/012042.

MARTÍNEZ-CAÑAS, R. \& RUÍZ-PALOMINO, P. (2011): "25 Years Of Science Parks In Spain: Towards A New Model Of Development", Review of Business Information Systems, 15(5), 17-24.

MESEGUER-MARTINEZ, A., POPA, S. \& SOTO-ACOSTA, P. (2020): "The instrumentation of science parks: an integrative framework of enabling factors", Journal of Intellectual Capital, DOI: 10.1108/JIC-11-2019-0264.

MOOK, L.I. (2007): "Social and Environmental Accounting: The expanded value added statement".

NG, W.K.B., APPEL-MEULENBROEK, R., CLOODT, M. \& ARENTZE, T. (2019): “Towards a segmentation of science parks: A typology study on science parks in Europe", Research Policy, 48(3), 719-732, DOI: 10.1016/j.respol.2018.11.004.

POONJAN, A. \& TANNER, A.N. (2020): "The role of regional contextual factors for science and technology parks: a conceptual framework", European Planning Studies, 28(2), 400-420, D0I: 10.1080/09654313.2019.1679093.

RETOLAZA, J.L. \& SAN-JOSE, L. (2018): “Contabilidad Social para el Bien Común”, Revista de Responsabilidad Social de la Empresa, 29, 95-122.

RETOLAZA, J.L., SAN-JOSE, L, \& RUIZ-ROQUEÑI, M. (2015): “Monetarizing the social value: theory and evidence", CIRIEC-España, Revista de Economía Pública, Social y Cooperativa, 83, 43-62.

RETOLAZA, J.L., SAN-JOSE, L. \& RUIZ-ROQUEÑI, M. (2016a): "Social Accounting for Sustainability: Monetizing the Social Value", Springer Briefs in Business, Springer, Cham, DOI: 10.1007/9783-319-13377-5.

RETOLAZA, J.L., SAN-JOSE, L. \& RUÍZ-ROQUEÑI, M. (2016b): “Polyhedral Model: Social Value Model for Stakeholders", In: Social Accounting for Sustainability: Monetizing the Social Value, Springer Briefs in Business, Springer, Cham, 37-51, D0I: 10.1007/978-3-319-13377-5_6.

RETOLAZA, J.L., AGUADO, R. \& SAN JOSE, L. (2020): "Social Accounting as an Enabling Tool to Develop Collective Organizational Citizenship Behavior in the Diocese of Bilbao", Frontiers in Psycology, 11(77), 1-11, D0I: 10.3389/fpsyg.2020.00077. 
RIBEIRO, J., HIGUCHI, A., BRONZO, M., VEIGA, R. \& DE FARIA, A. (2016): "A framework for the strategic management of science \& technology parks", Journal of Technology Management and Innovation, 11(4), 80-90, DOI: 10.4067/S0718-27242016000400011.

SAN-JOSE, L., RETOLAZA, J.L. \& FREEMAN, R.E. (2017): "Stakeholder Engagement at Extanobe: A Case Study of the New Story of Business", In: Freeman, R.E., Kujala, J. \& Sachs, S. (Eds.), Stakeholder Engagement: Clinical Research Cases, 46, 339-367, DOI: 10.1007/978-3-319-627854_13.

VÁSQUEZ-URRIAGO, Á.R., BARGE-GIL, A., RICO, A.M. \& PARASKEVOPOULOU, E. (2014): “The impact of science and technology parks on firms' product innovation: empirical evidence from Spain", Journal of Evolutionary Economics, 24(4), 835-873, D0I: 10.1007/s00191-013-0337-1.

WORLD BANK GROUP (2020a): Doing Business 2020 - Economy Profile of Spain.

WORLD BANK GROUP (2020b): Doing Business 2020 - Economy Profile of Sweden.

YAN, M.R., CHIEN, K.M., HONG, L.Y. \& YANG, T.N. (2018): "Evaluating the collaborative ecosystem for an innovation-driven economy: A systems analysis and case study of science parks", Sustainability, 10(3), 887, DOI: 10.3390/su10030887. 